Research Article

\title{
APPOINTMENT OF LEADER POSITION: STUDY ON THE REGIONAL GOVERNMENT OF WEST NUSA TENGGARA
}

\author{
Raihan Anwar*, Muchlis Rantoni Luddin, Agus Wibowo \\ Graduate School of Management, Faculty of Economics Universitas Negeri Jakarta
}

Article history:

Submission December 2021

Revised December 2021

Accepted December 2021

*Corresponding author:

E-mail:

raihanwar2@gmail.com

\begin{abstract}
This study aims to develop a model for leadership appointment positions in the Regional Government of Nusa Tenggara Barat. Using Yin multi case study method, data collection was carried out through observation, tracing and document analysis as well as in-depth interviews with informants consisting of two clusters (K-I and K-II). This research found that competence supports meritocracy, because the higher the competence, the better the meritocracy value. Meritocracy get the most dominant element, and political intervention has a negative role on employees and hinders the implementation of meritocracy, however, political functions in policy formulation and political control over the bureaucracy are needed. Local wisdom strengthens values of morality and integrity so as to fortify the unfair competition between civil servants and the discretion of regional heads. Talent management as urgent factor considering that more than half of the human resources are in a critical age. The study recommends developing a model for leadership appointment position with local wisdom and talent management elements that reinforce competence and meritocracy and inhibit political discretion towards superior performing leaders.
\end{abstract}

Keywords: Competence, Discretion, Local wisdom, Leadership position, Meritocracy, Talent management

\section{Introduction}

The government determines the autonomy policy in the administration of regional government through Law Number 22 of 1999 concerning Regional Autonomy, and Law Number 32 of 2004 concerning Regional Government as amended by Law Number 3 of 2005 and Law Number. 12 of 2008, then became Law Number 23 of 2014 concerning Regional Government and amended again by Law Number 9 of 2015 concerning the Second Amendment to Law Number 23 of 2014. The existence of this Law gives great powers to the Regional Government to manage their own households and enable the application of a new paradigm in managing the regional government system in running the bureaucracy efficiently, effectively, responsively, transparently and accountably according to community needs.

\section{How to cite:}

Anwar, R., Luddin, M. R., \& Wibowo, A. (2021). Appointment of Leader Position: Study on the Regional Government of West Nusa Tenggara. Indonesian Journal of Social Science Research, 2(2), 110 - 118. doi: 10.11594/ijssr.02.02.08 
Local government bureaucracy runs slowly, and very careful, this way of working makes it difficult for people who need fast, efficient, timely and simple services. Adnan (2013) summarizes some of bureaucratic weaknesses in the implementation of regional governance, including the organizational structure and work procedures made by each regional government which only accommodates officials in structural positions; lack of community participation; limited in transparency; overlapping work mechanisms among divisions of tasks make it difficult for internal circles and communities to deal with local governments; the politicization of civil servants is still symptomatic; an unhealthy career system creates unfair competition, which is not easily changed by bureaucratic apparatus.

The regional leader, who has absolute authority in the management of regional apparatus, ignores the processes and mechanisms for managing regional apparatus that meet general standards and regulations, causing mismanagement in recruitment, career path arrangements, and unclear apparatus placement (Murtadlo, Supriyono, Gani, Muluk, \& Java, 2015). This condition shows the image of the regional leader which acts arbitrarily in managing apparatus in their region. The Regional Government of West Nusa Tenggara Province, cannot be separated from the problems and assumptions that have occurred in other regions. Examples of cases that are still hot include, before the election, five echelon II officials, 52 echelon III officials, and 120 echelon IV supervisors were transferred by the Governor of West Nusa Tenggara (NTB) Muhammad Zainul Majdi.

This study aims to develop a model for the appointment of a leadership position with elements that can strengthen competence and meritocracy as well as reduce political intervention towards superior performing leaders. Focusing on the appointment of leadership positions to support and be able to answer research questions, the focus is supported by 5 (five) sub-focuses: (1) Fulfillment of competency requirements; (2) Implementation of the meritocracy system; (3) The role of political intervention; (4) The supporting role of local wisdom; and (5) Linkage of sub-focus elements in supporting the implementation of public service tasks.

\section{Conceptual Framework}

Most experts agree of five basic functions in the management process, namely: planning, organizing, staffing, leadership, control (Armstrong, 2012; Bogatova, 2017; Dessler, 2016; Itika, 2011). Whereas organizationally, the recruitment system as part of human resource management is a process of finding the most talented and motivated people (Kekale \& Varis, 2019; Mikhaylov, Julia, \& Eldar, 2014), in the initial process to get the suitable employees. Recruitment activities designed to influence the number of people applying for jobs; the type of person applying and / or the likelihood that those applying for a job will accept various positions if offered. Promotion is the internal movement or upward mobility of an employee within the organization to another job, higher up in the organizational hierarchy in a new job, and changes in salary, status, responsibilities, and job or job level. Mishandling in promotion process can lead to dissatisfaction and frustration among employees (Armstrong, 2012; Dessler, 2013; Noe, Hollenbeck, Gerhart, \& Wright, 2011; Phelan \& Lin, 2001; Riadini \& Bari, 2018). The promotion system affects majority aspects of the organization, so there are many factors that need to be considered such as the nature of the task environment, individual abilities, organizational structure, frequency of monitoring, performance criteria, and knowledge transfer (Armstrong, 2012; Dessler, 2013; Phelan \& Lin, 2001; Ferris, Hochwarter, Ronald, Harrell-Cook, \& Frink, 1999).

Furthermore, the competency mapping process assists organizations in developing clear strategies to develop the competence of their workforce so that organizational strategies must be designed to identify, maintain, and utilize competencies (Chouhan \& Srivastava, 2014). Wibowo (2017) states that competence is the ability to carry out or perform a job or task that is based on skills and knowledge and is supported by the work attitude demanded by the job. Competence shows skills or knowledge characterized by professionalism in a certain field as something most important, as superior 
in certain fields, with indicators of Knowledge, Skills, and individual skills including Attitude.

The standard Weberian bureaucratic model provides a central place for creating a professional, civil service who is apolitical, elected on the basis of merit, and who has considerable independence from political control (Ban, 2014). This model is now confronted by two things: in Western democracies by increasing pressure on the importance of bureaucratic political control as essential to democracy, and, on the other hand, in developing countries by the so-called politicization of the civil service, i.e. political leaders who control or at least affect appointments for positions in government. Although the results of research by Bellò and Spano (2015) show political intervention is inevitable in the bureaucracy and politicians and managers play two different roles and must carry out different activities. Managers are often required to find a delicate balance between fulfilling political demands, carrying out duties, and assuming the responsibilities, risks, and legal consequences of their actions, yet still, leave a strained relationship. From this perspective, then, recommends the general policy of maintaining the Weberian model with a merit system with a strict selection of civil servants and with a relatively minimal amount of political intervention.

The decentralization system occurs in local governments where political intervention is very pronounced, both through regional head policies, public policies, and through legislative oversight. Murtadlo et al. (2015) develop a relevant model for explaining current conditions, including in the management of staffing in the regions. The political position of the Regional Head apparatus is very dominant in determining who serves what without paying attention to regulations and selection results. Placing someone in a position prioritizes the political interests of the Regional Head in carrying out the vision and mission of the Regional Government. This domination pattern of the political bureaucracy places bureaucracy as political subordination (Murtadlo et al., 2015). Local wisdom is proven to be very important in supporting social, community and economic life. Shah, Shahjehan, Afsar, Afridi, and Saeed (2020) proves the importance of the role of local wisdom as an element that is included in policy making regarding teaching activities and community plantation so that it has a positive impact on the organization. Li, Easterby-Smith, Lyles, and Clark (2016) show the success of multinational organizations that combine global knowledge with local knowledge to support their business so as to increase productivity levels.

Based on the background, problem formulations, goals, benefits, and the concept of HRM, especially regarding recruitment, selection, promotion, competence and meritocracy, bureaucratic and political relations, local wisdom, and public services, the researchers compiled a conceptual framework for this study as shown in the picture: Researchers assume that these elements support the appointment of leadership positions. The political intervention box uses a vague arrow, because it is felt, but vague because according to law, it is prohibited.

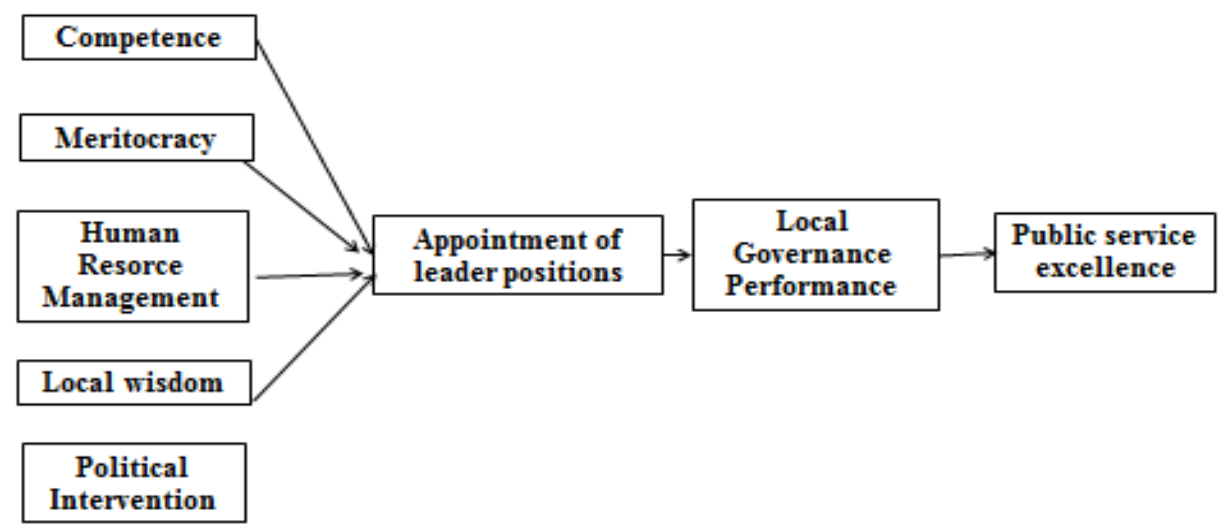

Figure 1 Conceptual framework 


\section{Method}

\section{Study site}

This research was conducted in mid-2019 to 2020 using in-depth interviews with 23 informants and 8 resource persons (K-I and K-II) consisting of Mid High Leader, First Stage Leader, Administrator, Supervisor and Head of Regional Officer Body, Organization Bureau Chief, Head of Development Body of the West Nusa Tenggara Provincial Government Human
Resources Development Agency, as well as community leaders, cultural and religious figures, and political party figures.

\section{Methods}

This study used a qualitative approach with a case study research method. The study design research adopted Yin (2003) adapted for further research.

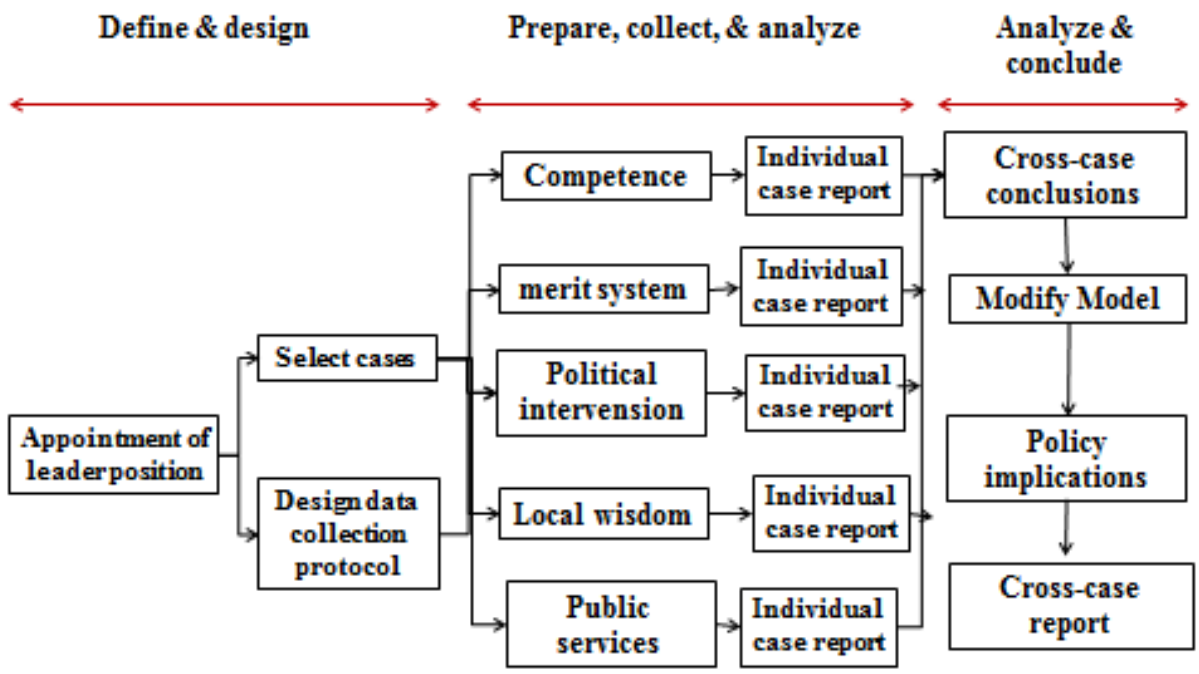

Figure 2. Case study research design for appointment of leaders in the Regional Government of West Nusa Tenggara Province

\section{Results and Discussion Competence}

7 (seven) informants from the first cluster (23 people) who were interviewed stated that they had not fully met the required criteria and suggested the need for technical training required to occupy certain positions. Meanwhile, 16 (sixteen) informants stated that the appointed officials had fulfilled all the requirements. When the grid of these questions was raised to two informants from the second cluster of politicians, they answered that candidates and officials appointed to leadership positions must meet administrative requirements, competency requirements, psychology tests and managerial abilities, as well as the statement of the Head of BKD. This data was then confirmed to the head of the HR department who stated that $90 \%$ of those appointed had met the required requirements, while $10 \%$ had not met the rank requirements, and were only temporary in nature. On the question of how many officials in the current workplace who do not meet the requirements or not yet are still appointed to leadership positions, 50\% of informants from the first cluster (KI) answered they did not know, 20\% answered that there were $5-10 \%$ officials who appointed did not meet the requirements of the rank requirements, and $30 \%$ of informants answered that less than $5 \%$ of the appointed officials did not meet the requirements, but it was not stated what elements were not fulfilled. Meanwhile, according to the political figures from the second cluster, gave an answer that: "Of the officials appointed to leadership positions, I think all of them have gone through the selection process at the Position Advisory Board so it is very unlikely that a person appointed to a position does not comply with the demands of the position likewise the answer given by the informant as well as the Primary High Leadership Officer 
in the HR sector. Furthermore, $15 \%$ of the informants stated that he had held echelon IV positions three times and three times held echelon III positions. As many as $70 \%$ stated that they were appointed because they had met the requirements of the position in terms of rank, competence, education, training, capacity and capability. $10 \%$ of informants gave reasons for their appointment to positions including because they had held structural/leadership positions since 2005. There were also $5 \%$ of informants who further stated that the reason for the appointment of the person concerned was based on location considerations.

In general, $85 \%$ of informants considered very important knowledge and skills regarding duties and functions in the workplace, especially those of a technical nature, because with this ability an ASN could work properly and correctly according to their performance targets. the performance of the unit including in solving problems and making decisions. $15 \%$ of informants considered managerial ability to be important and very decisive. The informants from the second cluster of Political Figures stated that knowledge and skills related to duties and functions were very important to provide certainty and quality of service to quickly and precisely.

Furthermore, the informants emphasized that capacity, professionalism and loyalty to duties are the main considerations in the appointment in a leadership position (KI-14; KI5; KI-13) informing that there are no special requirements that are prioritized because each requirement has a value and the weights that support each other and become a unity. The answer from K-I-3 states that the requirements for managerial abilities, maturity in thinking and acting, experience in occupying positions, communication skills, coordination and partnerships. Another group of informants answered that competence, education, age, work experience were the main requirements and considerations in selecting a leadership official. Some $80 \%$ of the informants stated that integrity is a very necessary requirement for those who hold leadership positions.

Based on document tracing and source triangulation interviews with 3 (three) echelon II official informants of work unit/SKPD leaders, it is known that the recruitment of prospective leadership officers is carried out in several ways and stages, according to the level of position that the candidate leadership will manage. For the recruitment of echelon II leadership positions, it is carried out through open bidding in accordance with the applicable regulations with several stages.

The fulfillment of competency requirements in research on the appointment of leadership positions in the Regional Government of West Nusa Tenggara Province (NTB) is still transitional, because with the Regulation of the Minister of PAN RB RI Number 38 of 2017 concerning Competency Standards for ASN Positions, the NTB Provincial Government must adjust the competency assessment system has existed before with the aspects and competency standards that are in the Regulation of the Minister of PAN RB RI Number 38 of 2017 concerning Competency Standards ASN position.

\section{Meritocracy}

The merit system has been used to assess individuals. Organizationally, the implementation of the merit system measured by 8 indicators, namely: (1) All positions already have a position competency standard; (2) Planning the needs of employees according to the workload; (3) The selection and promotion is carried out openly; (4) Has a career management consisting of planning, development, career patterns, and succession planning groups obtained from talent management; (5) Provide rewards and impose sanctions based on an objective and transparent performance assessment; (6) Implementing the code of ethics and code of conduct for ASN employees; (7) Planning and providing opportunities for competency development according to the results of performance appraisals; (8) Provide protection to ASN employees from acts of abuse of authority. It has not been fully implemented, as in point (4), it will only be implemented in 2021; point (7) Competency development has not been based on the results of performance appraisals, but on the proposed organizational needs.

Based on document studied and source triangulation interviews, it was found that the implementation of the merit system has so far been implemented by the NTB Provincial 
Government, following Law Number 5 of 2014 concerning ASN merit systems where ASN policies and management are based on fair qualifications, competence and performance. and fair without distinguishing the political background of race, color, religion, origin, gender, marital status, age and / or condition of disability (ASN Law Article 1 paragraph 22) which means merit system is the management of human resources based on competence through achievement. However, with the issuance of Government Regulation no. 11 of 2017 concerning Civil Servant Management, the NTB Provincial Government still needs to optimize its implementation to follow up on the Regulation of the Minister of PAN RB Number 3 of 2020 concerning ASN Talent Management, especially regarding the implementation of the talent pool and the ASN succession plan. Therefore, the Governor issued the Governor of West Nusa Tenggara Regulation No. 47 of 2020 concerning the Merit System in the Management of Civil Servants in the West Nusa Tenggara Provincial Government.

\section{Political intervention}

Basically, the informants rejected political intervention in the form of the discretion of the regional head in the appointment of office and agreed on the separation between politics and the bureaucracy. Weber argues that politicians and bureaucrats can work optimally if there are clear differences between the two roles. Politicians formulate policies, while the bureaucracy is the executor of policies. In short, informants reject discretion and agree with politicians/politicians in formulating policies by accommodating local wisdom and supporting the role of politicians through the DPRD as bureaucratic supervisors.

Political intervention in the bureaucracy can be in the form of Regional Head Discretion, Public Policy in the form of Regulations, as well as legislative control from the Regional People's Representative Council which in this study was derived through questions from informants. The answers of the informants can be grouped into three levels, namely informants who agree with and accept political intervention (K-I-11; K-I-14); informants who were forced to accept, voiced by K-I 9; K-I-19; K-I-20;
$\mathrm{K}-\mathrm{I}-21$, and K-I-23; and those who refuse political intervention practices (K-I 3; K-I-6; K-I-7; K-I 8; K-I-10; K-I-12; K-I-13; K-I-15 and K-I-18). Based on in-depth interviews with informants (KI), it can be suspected that the Regional Head's discretion occurred in several officials who said that: "In the two years since the current regional government, the informant has held the position of JPT Pratama for four times, or an administrator position on a moving basis. -move". Meanwhile, other informants stated that they held positions for more than three terms.

\section{Local wisdom}

The values of local wisdom such as the character of majoabuabu dahu, mutual ajinan, and tatas tuhu trasne which contain positive values in building a work ethic as a civil servant, coupled with "imtaq" activities are considered able to reduce sharp competition between employees as an impact of prioritizing competence and meritocracy. Serves to provide reinforcement of morality and integrity. If competence and meritocracy are carried out properly, the bureaucracy will become very rigid, so it is necessary to approach local wisdom that reinforces employee morality and integrity.

Overall, 23 (twenty three) informants understand the meaning of local wisdom well, it can be seen from the answers which, although varied, still show an understanding of local wisdom in the following answers. Fifteen informants gave answers that local wisdom is part of the culture of a society that cannot be separated and passed down from generation to generation. Referring to the case study of Nugroho et al. (2018)on local knowledge, it shows that public policy formulation is a politico-economic arena and therefore requires collaboration. The use of knowledge and evidence in public policy has become a popular topic of discussion over the last decade, including local wisdom as a real source of knowledge in public policy formulation. The potential of local wisdom can be used to grow its positive influence as one of the three types of knowledge that form public policy, namely scientific knowledge, professional knowledge, and local knowledge, where each plays its role. Local knowledge comes from the history and 
experiences of citizens and communities about how to survive and grow in their own environment. Based on the research results, local knowledge such as Majo Labu Dahu (shame and fear) and Tatas Tuhu Trasne (wise, diligent, tenacious, good morals) and mutual commitment are considered capable of encouraging work ethics towards superior human resources, so that political intervention is the formulation of policies for the Nusa Regional Government. West Southeast in terms of policy formulation to produce superior human resources, it is possible.

\section{The linkage between elements}

In supporting the implementation of public service duties, the linkage and involvement between sub-focus has proven to provide a strong foundation in achieving public service goals and achieving proud achievements for the community and for the civil servants as a whole. With officials who meet competency standards both technical competence, managerial competence, and socio-cultural competence, in providing public services he will follow the standard procedures set and apply public service protocols. By implementing a merit system, an official will try in such a way as to be able to provide the best public services. With competence and meritocracy that requires neutrality, if there is political intervention, he will be able to return to the original rules.

\section{Discussion}

Ministerial Regulation PAN RB RI Number 38 of 2017 concerning Competency Standards for ASN Positions, force the NTB Provincial Government to adjust its competency assessment system with existing competency aspects and standards, especially in the context of selecting JPT, Administrators and Supervisors. However, due to the unavailability of technical competency standards based on regulations prepared by the relevant ministries, the application of the Job Competency Standards applies to managerial and sociocultural competencies.

The NTB Provincial Government has human resources with the following structure: age 25 to 35 years are 1,536 (one thousand five hundred and thirty-six); ages 36 to 45 are 5043 (five thousand forty-three) and ages 46 to more than 56 years old are 7119 (seven thousand one hundred and nineteen) people. By looking at the requirements to occupy a position as stipulated in Government Regulation Number 11 of 2017 concerning Civil Servant Management where one of the requirements is to have one level experience under 3-4 years, and exceptions for Government Agencies that have implemented the Merit System in accordance with Article 134 of the Regulation Government Number 11 of 2017 concerning Management of Civil Servants regarding provisions regarding open JPT filling and how to compete, Regional Governments must do the recruitment carefully and immediately carry out talent management by creating a talent pool and compiling succession planning.

Various regulations have been established to maintain the neutrality of civil servants and civil servants from political influence, most recently through Law No.5 of 2014 concerning ASN Article 9 paragraph (2) which states that ASN employees must be free from the influence and intervention of all political groups and parties. This means that the involvement of civil servants in political party activities violates statutory provisions. The potential of local wisdom can be utilized to foster its positive influence as one of the three types of knowledge that shape public policy, namely science, professional knowledge, and wisdom, which each play a role. Public service is one indicator in government bureaucratic reform. Public service quality improvement programs are the main ones, by setting Service Standards, Implementing Minimum Service Standards (SPM) and increasing community participation in improving the quality of public services through the implementation of community satisfaction surveys.

Competency development still limited to organizational needs, not yet based on HR performance appraisals. While Technical competence is still limited to the ability to carry out tasks and functions, because there is no technical competency standards that should have been issued by the relevant ministry, so that high intensity of the transfer has resulted in HR being unable to work. Then, the budget limitations make leadership training limited, while HR management carried out by 3 different 
units, that can slows down the career development process. The absence of a talent pool has made the selection process for leadership positions more based on DUK and work experience or occupation. And local governments must be working hard to implement Government Regulation no. 11 of 2017 concerning Management of Civil Servants (PNS).

\section{Conclusion}

Competence supports meritocracy: the higher the competence, the better the meritocracy. Competence supported by local wisdom provides enrichment and strengthening of moral values and integrity. Meritocracy is the most dominant element in supporting the appointment of leadership positions because it is the public officer management system as a whole.

Political intervention in the form of discretion in appointments has a negative effect on employees so that it can reduce competence and hinder the implementation of meritocracy. However, the political function of policy formulation and political control over the bureaucracy is needed. Local wisdom strengthens the values of morality and integrity of competitive
ASN so that it can soften unfair competition and is expected to reduce the discretion of regional heads. Talent management that will be implemented becomes very urgent for the local government to recruit very carefully and immediately carry out talent management by creating a talent pool and preparing succession planning so that the required leadership formation can be fulfilled internally.

Based on research findings, we recommends to strengthening the model for leadership positions in the NTB Provincial Government to produce hight performance by requiring four main elements, such meritocracy, competence, talent management and local wisdom to reduce political intervention. By referring to the theory and empirical facts of bureaucratic and political relations, political intervention is still described. This shows that although in the latest legislation through Law No.5 of 2014 concerning ASN Article 9 paragraph (2) states that ASN employees must be free from the influence and intervention of all groups and political parties, as well as the involvement of civil servants in political activities, violating laws and regulations.

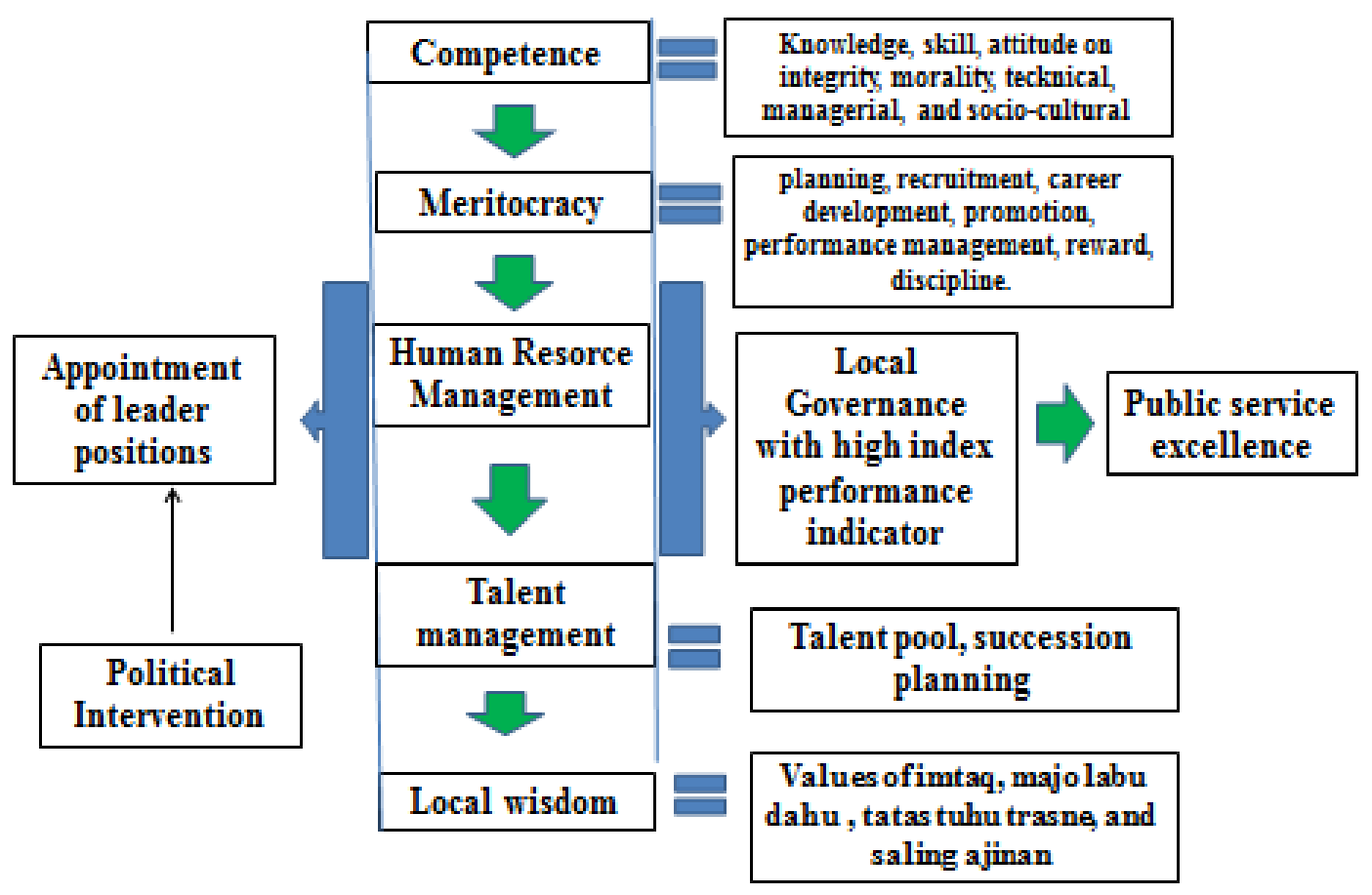

Figure 3 The improvement Model for appointment of a leadership positions 


\section{References}

Article in a Journal:

Adnan, M. F. (2013). Reformasi birokrasi pemerintahan daerah dalam upaya peningkatan pelayanan publik [Regional government bureaucratic reform in efforts to improve public services]. Humanus XII, 196-203.

https://doi.org/10.1017/CB09781107415324.00 $\underline{4}$

Bellò, B., \& Spano, A. (2015). Governing the purple zone: How politicians influence public managers. Eur. Manag. J. 33, 354-365. https://doi.org/10.1016/j.emj.2015.04.002

Bogatova, M. (2017). Improving Recruitment, selection and retention of employees. Bachelor Thesis. South-Eastern Finland University of Applied Science. https://doi.org/10.1242/bio.022046

Chouhan, V. S., \& Srivastava, S. (2014). Understanding competencies and competency modeling: A literature survey. IOSR Journal of Business and Management, 16, 14-22. https://doi.org/10.9790/487X.

Ferris, G. R., Hochwarter, W. A., Ronald, B. M., HarrellCook, G., \& Frink, D. D. (1999). Human resources management: Some new directions. J. Manage. 25, 385-415.

https://doi.org/10.1177/014920639902500306

Li, S., Easterby-Smith, M., Lyles, M. A., Clark, T. (2016). Tapping the power of local knowledge: A localglobal interactive perspective. J. World Bus. 51, 641-653.

https://doi.org/10.1016/i.jwb.2016.04.001

Mikhaylov F, Julia K, Eldar S (2014). Current Tendencies of the Development of Service of Human Resources Management. Procedia - Soc. Behav. Sci. 150, 330335.

https://doi.org/10.1016/i.sbspro.2014.09.072

Phelan, S., \& Lin, Z. (2001). Promotion systems and organizational performance: A contingency model. comput. math. organ. Theory 7, 207-232. https://doi.org/10.1023/A:1011986519310

Shah, S. I., Shahjehan, A., Afsar, B., Afridi, S. A., \& Saeed, B. B. (2020). The dynamics of leader technical competence, subordinate learning, and innovative work behaviors in high-tech, knowledge-based industry.
Econ. Res. Istraz. 33,623-638. https://doi.org/10.1080/1331677X.2019.169914 $\underline{0}$

A book:

Armstrong, M. (2012). Armstrong's Handbook of Human Resource Management Practice. 12th ed. London: SAGE Publisher.

Ban, C. (2014). Drawing the Line between Political Control and Politicization: An Analysis of Public Administration Theory. In: Annual Meeting of NISPAcee. Budapest, pp. 1-13

Dessler, G. (2013). Human Resource Management. $13^{\text {th }}$ ed. Harlow: Pearson Education Limited.

Dessler, G. (2016). Fundamentals of Human Resource Management. $4^{\text {th }}$ ed. Harlow: Pearson Education Limited

Itika, J. S. (2011). Fundamentals of Human Resource Management. $2^{\text {nd }}$ ed. Leiden: African STudies Centre.

Kekale J, Varis J (2019). Responsible University: In Search of HR and Leadership Solutions, in: Sorensen, M.. et al (Ed.), The Responsible University. pp. 233-256

Murtadlo, Supriyono, B., Gani, A. Y. A., Muluk, K., \& Java, E. (2015). The role of district head in the management of local government employees: Study politization of management of local employees. Public Policy Adm. Res. 5, 33-39.

Noe, R. A., Hollenbeck, J. R., Gerhart, B., \& Wright, P. M. (2011). Fundamentals of Human Resource Management. $4^{\text {th }}$ ed. New York : McGraw-Hill.

Nugroho, K., Carden, F., \& Antlov, H. (2018). Local Knowledge Matters: Power, Context and Policy Making in Indonesia. Bristol, UK; Chicago, IL, USA: Policy PressPolicy Press

Riadini, B., \& Bari, AA. (2018). Perencanaan Suksesi Urgensi, Model, dan Implementasi [Urgency Succession Planning, Model, and Implementation]. Sleman: Deepublish

Wibowo. (2017). Manajemen Kinerja. Edisi ke 6. [Performance Management (Sixth edition)]. Jakarta: Rajawali Pers

Yin, K. R. (2003). Case Study Research: Design and Methods. $3^{\text {rd }}$ ed. Califronia: SAGE Publication. 